\title{
The winning code and its enlightenment for a strong leader
}

\section{Yu Liao}

Wuhan City CollegeWuhan, China

Email: tomliao-898@163.com

\begin{abstract}
:
Leaders need to lead people to achieve organizational goals. Strong influence is a common feature of good leaders. The influence comes from the powerful image of the leader through his words and deeds, In the world's big power game, Russian leader Putin showed strong leadership and was admired and admired by the people, which strengthened his leadership in Russia. Based on the analysis of how Putin expresses his strong leadership image, this paper discusses the winning code for a strong leader and the way of shaping the positive identity of the leadership image.
\end{abstract}

Keywords : Leadership image Level of identification Shaping pathways

【Introduction to the author】 Yu Liao (1970—), Male, Wuhan, Hubei, Master's degree, Associate Professor, Wuhan City College, Research interests include human resource management and leadership behavior 
Leadership is an act or process by which a leader exerts power to influence his subordinates in order to achieve organizational goals. A political leader is a person who occupies a leading position in a country or a collective. While it's important to have the ability, strength, and experience to be an effective leader, something more intangible -- what many people call charisma or define as a leader's temperament -- plays a big role. A leader shows his strong image in a certain way and improves his positive discrimination, which leads to his followers'compliance and love.

\section{Powerful leaders and their influence}

Leadership is the ability to lead, it is a leader to grasp the mission of the organization and mobilize people around this mission struggle. A strong leader is a leader who has a strong presence and influence in the leadership process, "strong" is a leadership style, is a king style, is a passionate fighting spirit, but also a kind of leadership wisdom. "strong" is nothing more than "hard" to themselves, "hard" to employees, and "hard" to competitors. This may seem cruel, but if you don't do it, it will be difficult for the organization to be truly strong and to go further, social Competition will be "cruel" to you and you will be eliminated. If you want to be invincible, you must be ruthless. The basic aim of competition is to surpass your rivals, to be higher and stronger than others! A team that works "hard" with each other is always stronger than individuals.

As the saying goes, " An incapable soldier is just a soldier, but an incapable commander would bring out a team of incapable soldiers." , a team, only the leadership is strong enough, subordinates can be self-conscious, the team can have combat effectiveness. A flock of lions led by a sheep is no match for a flock of sheep led by a lion, demonstrating the importance of leadership to an organization. The strength of a leader is not cold and tough, but a strong

control over the thoughts and feelings of his subordinates, which requires a strong heart, a strong presence, and a strong influence. 


\section{The charisma of a strong leader increases the public's perception of}

\section{leadership}

The charisma of a strong leader increases the public's perception of leadership. The so-called identification is to identify the degree of recognition, high identification is to have some special characteristics from the ordinary normal stand out, at a glance for it, it is different. ${ }^{[1]}$

The term identifiability comes from the business world, and in marketing it's called brand recognition, which refers to how well people know a brand, a product, or an ad when the name is described or mentioned. It helps enterprises to know whether their own brand publicity and communication can let the brand be recognized in the market. Good and distinct brand recognition helps to enhance the market competitiveness of the brand, can effectively avoid the brand homogeneity brings the market competitive power insufficiency and so on question. In the fierce market competition, the individuality of many industries'products gradually converges, and the commonness of Industries is particularly prominent, in order to seek a breakthrough many enterprises from the brand name, brand image, service behavior, service value to enhance the brand recognition.

An ordinary person with no discernment is a person who has nothing to show for himself. He stands in the crowd and no one will see him. As an ordinary person, you may be anonymous, it may be a matter of personal pursuit, but as a leader or a politician you are too, it is a big problem. The power of a politician in performing government functions is given to him by the people, and he is required to make profits for the people, solve the livelihood problems of the people, promote economic development, improve the quality of life for the people, and safeguard the country's image and sovereignty abroad. To be a qualified political figure, he has to constantly shape and strengthen the public recognition of his positive image in the performance of his duties. When you have a high degree of public recognition as a leader or leader, you can quickly stand out from the community and have a strong leadership influence.

When it comes to the public's perception of leadership, it comes first to the laws of human cognition. From the point of view of behavior and psychology, human cognitive process is a very complicated process. It is a process of processing information, the psychological activity 
that reflects the characteristics and internal relations of objective things from the appearance to the essence. It is composed of the cognitive elements of human feeling, perception, memory, thinking and imagination. Attention is a psychological characteristic accompanying with mental activities. ${ }^{[2]}$

Sensation is the starting point of our understanding of the world. It is the process by which people directly reflect the individual properties of the objective things, such as the color, shape, sound, etc.The senses are divided into external senses (sight, hearing, taste, smell, touch) and internal senses (sense of balance, sense of motion, sense of body) . If feel color, bright and dark, tone, beautiful and ugly, thick and thin, soft and hard, etc. The external information provided by audio-visual system accounts for $80 \sim 90 \%$ of the information acquired by people. Therefore, when leaders or political figures carry out activities that affect the public, they must take full account of the public's audio-visual perception and achieve a more satisfactory level of effect through skillful handling and prior arrangement.

Perception is the comprehensive reflection of the human brain on the whole of the objective things directly acting on the sense organs. Is a more complex psychological phenomenon, is the brain to different sensory information processing results. Perception is based on feeling, but it is not a simple collection of feeling, but a whole image formed on the basis of synthesizing many kinds of feeling. At this point, what we realize is no longer the individual attributes or characteristics of things, but the connection and relationship of things. In "blind men and an elephant" fables, as they are known from an early age, the characters have different perceptions of the elephant, based on associations between their senses and the past in their brains.

Memory is the recognition, retention, representation or recognition of things experienced by the human brain, which is the basis of higher mental activities such as thinking and imagination. Memory, as a basic psychological process, is closely related to other psychological activities. Memory is the basic function of people's study, work and life. The process of transforming abstract disorder into pictorial order is the key to memory. The basic process of memory is composed of three links: memory, retention, recollection and recognition. These three links are related and restricted each other. Memorization is the 
premise of retention, without which there is no recollection and recognition, which is the index to test the effect of memorization and retention. ${ }^{[3]}$

Thinking is the indirect reflection process of the general attribute and internal relation of the objective things in people's mind. It reflects the essential features and general laws of things. And, through language activities, people to their own thinking activities, the results of understanding the activities of communication with others, to accept the experience of others. In addition, people also have imaginary activities, which are carried out by means of concrete images preserved in the mind.

Therefore, to improve the positive image of leaders, it is necessary to be based on the cognitive process of the above-mentioned people in each link.

\section{The winning password for a strong leader}

So what is the winning formula for a strong leader? The short answer is to increase the visibility of their strong, positive image in the eyes of the public or their followers. Take the example of Russian President Putin.

Vladimir Vladimirovich Putin (born on October 7,1952), a Saint Petersburg native, graduated from the Saint Petersburg State University, was elected the second president of Russia in 2000, won re-election in 2004, and served as president from 2000 to 2008, russia has made considerable military and political strength, in the democratic aspects of a lot of controversy, is a "strongman president. ".He became Prime Minister of Russia in 2008. Putin declared his candidacy for president again in 2012, and on March 5,2012, Putin won his second term as Russia's president. He was sworn in as Russia's fourth president for a six-year term on 7 May 2012. On December 6,2017, Putin announced his candidacy for the 2018 Russian presidential election. On March 18,2018, Russia's presidential election ended with Putin winning a fourth term, with 76.1 percent of the vote. On February 13,2015, Russians trusted Putin 85 percent, a record high. On November 5 of the same year, Putin was ranked No. 1 on Forbes Magazine's list of the top 10 most influential people in the world in 2015.

Putin, who has served four terms as president and twice as Prime Minister of Russia, is a 
skilled and cautious man with a wide range of interests and interests in his life. Playing the piano, accordion, swimming, horseback shooting, fishing, boxing, wrestling, judo, and mountain skiing, Putin was proficient in everything; flying into the sky, diving into the lake, Putin can do anything. Putin is energetic and capable, and his image as a tough guy with both strength and tenderness has taken hold. "Putin is a good man in the eyes of women and a real man in the eyes of men, " said one netizen. ${ }^{[4]}$

Here's an analysis of how Putin, a strong leader in the long run, has gained national popularity by raising his own profile:

\subsection{Show a strong physique and create a "tough guy" image}

To this day, no head of state has more hobbies and energy than Putin, who can go shirtless fishing in Siberia, fly fighter jets and Tame Tigers in the Siberian jungle, catching whales in the Far East; riding horses in frozen regions; diving 1,400 meters into Lake Baikal in a pocket submarine; riding a snowmobile on a snowmobile to the snow plain in a majestic manner; and driving a heavy motorcycle in sunglasses. Ever since he undressed on a fishing boat and showed off his pecs, his muscular physique has earned him a reputation as a tough guy.

No matter how busy Putin was, he continued to exercise and take part in all kinds of outdoor activities, swimming, wrestling, fighting, horseback riding, fishing, and even motorcycle riding, scuba diving, and flying, that's how he keeps his energy and his charm. Putin was not only concerned about his own physical activity, but was also concerned about the development of Russian sports and was interested in promoting a healthy lifestyle to the whole society. To promote and popularize judo in Russia, Putin and Shestakov, president of the Russian Judo Association, wrote a textbook on judo for Russian judo athletes. As soon as the textbook was published, it became a national best-seller. Since 2000, Russia has held the annual "president of Russia Cup" judo international competition, Putin has always been present at the scene, personally to award the athletes.

\subsection{To publicly present himself as a "good man."}

Putin does not drink and loves his family, and when editors of some major Western newspapers asked Putin if his wife was ready to appear in public as first lady, "She doesn't 
like to be in the public eye, " Putin replied, "and the modern media is ruthless, and not everyone is prepared to deal with it. " He went on to implore the media: "As you can see, my family is not in politics or business, and I implore you not to disturb them and give them a peaceful life. " With the brilliance of Putin on the political stage, most Russians see him as a man who can lead Russia to renewal and strength. In the eyes of supporters, Putin is Russia's "savior", in the eyes of female fans, Putin is their most perfect "good man" . In Russia, Putin even has his own fan club for women, and though he is said to be about 1.70 metres tall, he has a certain charm. In a Russian poll, Putin was overwhelmingly voted the most attractive man in the world by women.

\subsection{To mold the image of "Hero" with the ability of governing the country}

In Russia, Putin is known as "the most respected politician" . He is known for his tough-guy image and gentle, people-friendly leadership style, can arouse the Russian people's "Hero" complex. During his first two terms as president, Putin followed the original intention of restoring the image of Russia as a great power by taking corresponding measures at home, strengthening the power of the federal government, rectifying the economic order, cracking down on financial oligarchs and strengthening the army We will make efforts to improve the international environment, expand space, safeguard our national interests and gradually restore our status as a strong country on the international stage. Putin is the only Russian leader to speak to a foreign head of state in a foreign language for nearly a century, with the exception of Vladimir Lenin. He had a long talk with the German Chancellor, a Jaunty Banter with Obama, and a gentlemanly visit to the queen in a black Tuxedo. When it comes to counter-terrorism, his determination to "drown Chechen mobsters in toilets" speaks volumes about his candor.

At the same time, Putin has a tough, tender side. For 10 years in a row, he has conducted live television and radio contact activities with the Russian people, answering directly all kinds of questions from the people, and showing a warm and amiable side in equal and near-person conversations. During his visits to Japan, he competed with small rural judo players; he helped students escape when their songs got stuck; villagers invited him to swim and he jumped into the river without saying a word; Putin played the violin at a charity concert in his 
hometown, with the athletes, he squatted in the front row in an informal way...

\subsection{Strong diplomacy to preserve national dignity}

In diplomacy, despite the great pressure from the West, the diplomatic crisis management has achieved remarkable results, and has maintained Russia's international status and national dignity, which is the most acclaimed achievement of the Russian elite and common people. A few years ago, Russia sent troops to Syria, which achieved unexpected results, not only initially realizing Russia's diplomatic expansion into the Middle East, but also through extensive cooperation with Iran, Turkey, Iraq and other countries, it promises a "non-western-led end" to the war in Syria. Although Putin later announced that he would withdraw most of his military personnel from Syria, Russia has firmly established itself in western Asia and the Middle East through the Syrian war. In addition, the resolution of the conflict in Ukraine was an important turning point for Russia to reverse the expansion process of the West in the years after the Cold War.

\subsection{Crimean events show boldness}

In March 2018, Russian troops led by pro-russian forces in Crimea entered the Crimean Peninsula. Most of Crimea's existing Ukrainian troops have fled, while a few have defected to Russian forces. Soon after, a referendum was held on the Crimean Peninsula, organized by Russians and pro-russian Crimeans. ninety-eight percent of crimeans decided to leave Ukraine and join Russia. At the behest of President Putin, Russia's parliament has effectively written Crimea into its constitution. Although international public opinion has been far more critical of Russia than supportive of it, it is in Russia's interest to break up Ukraine, which is already determined to join NATO and the European Union, russia's Black Sea Fleet bases were secured, NATO driven Ukraine was avoided, Strait of Kerch was completely under control, and Sea of Azov was surrounded on three sides by Russian territory, effectively becoming a Russian controlled inland sea, took control of the Crimean Peninsula. Taking back Crimea satisfies the strong demands of the people at home and increases the national confidence and cohesion of the Russian people.

\subsection{Aid to Syria shows boldness}


In 2011, the Syrian opposition formed an armed force and launched an attack on Syrian government forces. Since then, the prolonged Syrian war, which has lasted for eight years, has broken out, the Bashar al-Assad administration was initially overwhelmed by U.S. backed opposition forces, but since 2015, when President Putin of Russia, undaunted by the U.S. superpower, ordered troops into Syria in an emergency, with Iran's help, Bashar al-Assad's forces, arguably the Out from Under, regained much of the ground they had lost. At the beginning of the war, Syria was Russia's only overseas base, and if Russia once again turned its back on Syria, as it did in Iraq during the Gulf War, then Russia could lose its voice in the Middle East forever. Once Syria is lost, then Western countries, especially the United States, can openly station troops in Syria. NATO will also take the opportunity to control the Black Sea and the Mediterranean Sea. Then Russia will be attacked from both sides, such a scenario would be unwelcome to Putin, while Russia maintains its great power image by projecting a presence in the Middle East. Putin's boldness earned him public respect. The famous Russian political scientist Mikhail Gorbachev once said that the Russian nation has always been looking for a leader, from the Mikhail Gorbachev to Boris Yeltsin to Putin, the people are always looking for a leader, it turned out that Putin was the kind of leader who could bring stability and glory, and that maintaining Russia's image as a great power was an important guarantee of Putin's leadership.

\section{The positive discrimination of strong leader image}

The influence of leaders consists of power influence and non-power influence. Power influence, also called hard power, refers to the influence that comes from the position, position and power given to leaders by society and organizations. This kind of influence is take "legally" as the pillar, is one kind of compulsory influence. As for the leaders, the society has given them certain power and authority by means of election, appointment, self-recommendation or recruitment, to be led on the generation of coercive force (such as reward and punishment command, distribution of work, job promotion and so on) and fear. The influence of position factor is the compulsory power based on the legal form of the leader. 
Non-power influence, also called soft power, refers to the influence produced by the leader's individual behavior and quality. It's not just for leaders. There are four main aspects: the leader's character mainly includes morals, conduct, personality, style and so on. Character is mainly manifested in the mental activities, words and deeds of leaders. There is no limit to the power of example. Leaders with noble character, easy to make the leaders have a sense of respect, and induce them to imitate and identify, thus producing greater appeal, mobilization, persuasion. A leader's intelligence, ability to work, and professionalism. It is an important condition for a leader to be competent for the leading position and complete the leading work. The ability and ability of leaders is the main factor of their influence. A talented leader will inspire a sense of admiration in those who are led. Admiration is a kind of psychological magnetism, which can attract people to accept its influence consciously. Modern leadership activities put forward higher requirements for the knowledge reserves and level of leaders. Leaders with rich scientific knowledge can easily gain the trust of the leaders when they guide work, publicize and organize the masses, communicate and coordinate relations, create a sense of trust in the person being led, which will inevitably increase the leader's influence. Emotion is the inner experience of People's preference to the objective object, and it is the synthesis of their emotion and emotion. People establish a good emotional relationship between people, can produce a sense of intimacy. In a sense of intimacy between people, the mutual attraction is large, each other's influence on the high. A leader is affable, considerate and caring for subordinates at all times, and the relationship between the masses is very harmonious, its influence is often higher.

Therefore, from the above study of Putin's performance in power case, it can be seen that he better from these aspects to improve their recognition in front of the public, and generally loved by the public.

In addition to this, there are several ways we can improve the positive image of our leaders:

\subsection{Accurate personal identifiability positioning}

In the market competition, a brand must have a very clear and independent brand positioning to win customers and the market, such as Vipshop, its brand positioning is very intuitive: "A special sale site", to be distinguished from other shopping website, reflected not only 
professional sex, also raised recognizability. Leaders are the same, to establish intuitive personality differences, accurate positioning, improve the degree of identification. On December 31,1999, Boris Yeltsin gave a televised speech "handing over the reins" to Putin, leaving behind a mess of political and economic difficulties since the collapse of the Soviet Union. Boris Yeltsin dismissed his cabinet four times between 1998 and 1999, each time defusing short term political crises but failing to end recessions. As he said, Russia should enter the new century with a new generation of politicians, with a new generation of smart, strong and energetic people.

Based on the needs of the times and the public's hope that Putin will lead Russia out of trouble, Putin correctly positioned himself as personally identifiable from the beginning of his presidency: Russia desperately needs the will and conviction of the state (implying that he is the representative) . In order to make Russia rich and powerful, it needs to establish "Russian thought", whose elements are patriotism, great power consciousness, statism and social unity. It is positioned as a powerful "saviour" of a declining Russia. The recognition of this position was reinforced later by his re-election rhetoric of "give me 20 years to give you a strong Russia" .

\subsection{Create a unique visual presentation of personal identity}

We have five senses, sight, hearing, smell, taste, touch, and sight and hearing are usually the main channels for the transmission and reception of information. By consciously creating visual representations that the public likes or accepts, leaders can engage their audiences and improve their own identity.

Since coming to power, Putin has created his own powerful visual representation of "men of Russia" . After the collapse of the Soviet Union, between 1991 and 1998, Russia's GDP fell by 46 per cent and total investment by 81 per cent. Compared with 1990, Russia's GDP in 1998 decreased by 51 per cent and total investment by 84 per cent. It is in such dire circumstances that Putin has been brought into office when Russia's transformation from a superpower to a second-rate state has been "devastated" . Putin's rise to power has been accompanied by howls to restore the dignity of Russia's great powers, as previous administrations have shown little tolerance for the US led West. In 2001, Putin imposed a Soviet era military presence in 
Central Asia, despite popular opposition, to announce to the world that the bloody Russia was back. In 2003, Putin launched a nationwide campaign against corruption, in which scores of corrupt officials and police officers were jailed. In March 2014, Putin recognized the independence of the Republic of Crimea. On March 20, Putin approved Crimea's accession to the Russian Federation. In the face of Russia's aggressive behavior, the western group led by the United States, though vigorously "objection, objection, objection" , but there is no effective concrete means, so far Crimea has been firmly held by Russia. Under Putin's leadership, Russia strengthened the power of the federal government at home, cleaned up the economic order, cracked down on the financial oligarchy, and made vigorous efforts to intervene in international affairs, improve the international environment, expand diplomatic space, and safeguard its own interests. In addition, tough Guy Putin from time to time to "show muscle" to the world, skiing, judo, ice hockey, car racing proficiency. In addition to the male hormones that emanate from his muscles, Putin's boldness and quickness in his dealings with the West, and his ability to get ahead of everything else, have earned him a lot of praise.

\subsection{Tell a good personal brand story to increase recognition}

Example is a kind of upward force to lead the public forward, found examples, set examples, propaganda examples, good example of the story, has become an important part of the ideological construction of a country. We often say that "good example is visible philosophy, " good example of the story, publicity good example of the deeds, condense good example of the character of great significance to the education of the masses. It also increases the impact and recognition of a leader who is the protagonist of a role model story.

A photo of Russian President Putin riding a bear went viral on the Internet in 2018, sparking heated debate among netizens. Whether the photo is real remains a mystery. In an interview with NBC, Putin said he had seen pictures circulating on the Internet, and he said, there are a lot of pictures of me at work that people don't seem to care about. I've seen this picture, but I've never ridden a bear. But they do exist. In fact, the original image was taken in 2009 while Putin was on vacation in southern Siberia. The forger simply flips Putin upside down in a clumsy attempt to create a visual spectacle of Putin riding a bear. But Russian officials do not object to such spoofs, and instead provide a platform for such interesting creations, which 
were exhibited by patriotic artists at a 2017 Pro Putin art exhibition. In addition, other hand made figurines of Putin in arm wrestling with the West, Chinese martial arts, bold and careful image has been produced. This is a unique way to "tell a story" in order to improve the identification of leaders. It can be seen that although this image is a fake, it has become more popular than the original Internet because it resonates with the common will of the Russian people. It also shows that the Russians have gathered a strong will in the predicament of Western sanctions, it is the bear that embodies the spirit of the Russian people: Strength, fearlessness, courage and strength! ${ }^{[5]}$ 。Of course, it would be better if it were true.

In short, leadership charm is an important carrier of group will power and an indispensable basic quality of a good leader. Through the shaping of external image based on power and non-power influence, leaders can improve their recognition among the public to become strong leaders, in order to more conducive to their subsequent leadership behavior.

\section{References}

[1] Identifiability-360encyclopedia.https://baike.so.com/doc/2454480-2594528.html.

[2] Cognitive process-360encyclopedia.https://baike.so.com/doc/942053-995701.html

[3] Memory-360encyclopedia.https://baike.so.com/doc/5405514-5643290.html

[4] Vladimir Vladimirovich Putin-360encyclopedia. https://baike.so.com/doc/2889460-3049294.html

[5] Is it true that Putin rode a bear? This time, he responded in person! - china-eastern military.http://mil.eastday.com/a/180310204125606.html?qid=01618 